\title{
Defining and measuring river basin sustainability: a case study of the Yellow River
}

\author{
H. Wu ${ }^{1}$, R. Darton ${ }^{2} \&$ A. Borthwick ${ }^{3}$ \\ ${ }^{1}$ Institute of Water Policy, Lee Kuan Yew School of Public Policy, \\ National University of Singapore, Singapore \\ ${ }^{2}$ Department of Engineering Science, University of Oxford, UK \\ ${ }^{3}$ School of Engineering, University of Edinburgh, UK
}

\begin{abstract}
This paper defines sustainability of a river basin and further investigated the use of sustainability indicators for integrated assessment of a large river basin. The concept of river sustainability concerns not only the ecological condition of the river course, but also socioeconomic activities in the river basin. River sustainability is concerned with resource sufficiency, resilience to water-related risks, access to water supply and other services, the productive use of water, and fairness between different users and generations.

A case study is undertaken to examine the underlying sustainability of the Yellow River in China. The Process Analysis Method is employed for developing a sustainability assessment framework. Through systematic process, a tailored indicator set is selected and categorized under three domains, namely, environmental performance, social wellbeing, and economic development. Extensive fieldwork was carried out in order to conduct stakeholder interviews and collect comprehensive data. The assessment provides policy-makers and river managers with a holistic review of the river basin, which can be used for underpinning integrated river basin management policies.
\end{abstract}

Keywords: river basin, sustainability, indicators and indices, assessment.

\section{Introduction}

Sustainable development has gained widespread acceptance since it was put on the global agenda by the World Commission on Environment and Development in 1987. The most quoted definition of sustainable development, published in the 
Brundtland Report [1], refers to 'development that meets the needs of the present without compromising the ability of future generations to meet their own needs'. It illustrates the dilemma inherent in human development between meeting human needs, in particular the essential needs of the world's poor, and the limitations on the environment's ability to cope with the consequences. River basins stand at the centre of emerging challenges in terms of water security, food production, socioeconomic development, as well as climate change. The management of river basins therefore needs to recognize and incorporate broad objectives of meeting needs and coping with uncertainties.

In this study, we introduce the term, river sustainability, to incorporate the river system's interconnected physical, biological and socio-economic functions. Sustainability of a river basin is determined by whether the river system can support the long-term ecological and socioeconomic functions of the river basin as a whole. An explicit definition is provided for river sustainability in keeping with the principles of sustainability, which is backed up by quantitative measurements. Five perspectives have been identified to describe sustainability of river system: sufficient resource, resilience to water-related risks, access to water supply and other services, productive use of water, and fairness between different users and generations. Such perspectives are used for identifying impacts on sustainability and addressing impact generators, further for setting benchmarks, and for identifying appropriate targets to improve sustainability.

The Process Analysis Method (PAM) developed by Chee Tahir and Darton [20] is employed to guide indicator selection. Serving as the guideline, the PAM presents a systematic approach for structuring the assessment, in terms of addressing the perspectives of sustainability and selecting indicators. It enables the development of a comprehensive set of sustainability indicators and metrics tailored to a particular river system. A case study is undertaken to examine the underlying sustainability of the Yellow River in China. PAM is employed for developing a structured, comprehensive sustainability assessment framework. Intensive stakeholder consultation have been undertaken, to identify emerging issues and impacts on sustainability. Through the analysis, we aim to give a holistic review of the Yellow River's performance from 1950 to 2010. This framework reveals the trade-offs between three domains of sustainability, namely, environmental performance, social wellbeing, and economic development, further help identify key elements for integrated river basin management.

\section{Sustainability measurements and indicators}

In the 25 years since the Brundtland Report was published, much effort has been dedicated to applying this concept in practical situations. Quantitative measurements of sustainability are required in order to evaluate to what extent sustainability is being achieved, to track progress towards sustainability, and to provide information and guidelines for development projects $[2,3]$. The need to assess sustainability has given rise to the development of various approaches and tools, which include indicators, benchmarks, audits, indices, accounting parameters, as well as assessment appraisal and other reporting systems [4]. 
Sustainability indicators are increasingly recognised as useful tools, and have been extensively applied to measure different dimensions of sustainability. Sustainable development indicators (SDIs) have been intensively used to improve stakeholder engagement and to guide policy-making [4-7]. The indicator set results in metrics which are a collection of carefully chosen measurements that quantify each indicator and cover relevant environmental, economic and social impacts. The strength of the SDIs set lies in its ability to summarise and focus attention on the essential elements of a complex situation. The key decision inherent in sustainability assessment by using indicators is the choice of exactly which indicators to include in a set, and which to omit. This process of selection needs to be both transparent, and to follow a methodology designed to produce an indicator set for a particular purpose [8].

Water resources is strategically vital to sustainable development. Many indicators have been developed to assess and monitor water-related vulnerabilities and risks. A widely used water stress or water scarcity indicator was proposed by Falkenmark in 1989. This simple metric is represented by the total annual runoff available for human use. According to the Falkenmark indicator, a country or region is in the status of 'water stress' or 'water scarcity' when water supplies fall below $1,700 \mathrm{~m}^{3}$ or $1,000 \mathrm{~m}^{3}$ per capita per year respectively [9]. Gleick (1996) introduced the term 'basic water requirements' to describe water used for four basic human needs: drinking water for survival; water for human hygiene; water for sanitation services; and water for certain household needs such as preparing food. Gleick suggested that 50 litres water per person per day is the minimum required to meet these basic needs, regardless of an individual's economic, social, or political status. Taking fluctuations in water availability and social adaptive capacity into account, Ohlsson developed a social resources water stress/scarcity index [10]. Based on the Falkenmark indicator weighted according to the UNDP Human Development Index, the social resources water stress/scarcity index captures the social impacts of water resources, and is claimed to be more useful than earlier indices $[10,11]$.

These measurements are carefully designed to describe a critical aspect of the water situation, i.e. water stress, water use efficiency. They are simple and straightforward. They are widely used for benchmarking, informing the public and raising general awareness. However, the information provided by the singledimension measure is limited. Comprehensive measurements, incorporating different concerns of water, are needed for multi-criteria decision-making. River sustainability assessment takes a different approach to the above methods which focus on just one or two critical aspects of the water. Based on comprehensive reviews of the basin's environmental, social and economic impacts, river sustainability assessment provide results which are holistic, well-structured, and easy to understand and use. 


\section{Defining and measuring river sustainability}

\subsection{Working definition of river sustainability}

The concept of river health evolved from scientific principles and changing societal values concerning integrated river basin management [12-15]. The maintenance and restoration of 'healthy' river systems, often aimed towards a biologically pristine condition of a river, have become important objectives of environment and water resources management $[16,17]$. Distinct from river health, river sustainability comprises not only the natural value of the river course from an ecological perspective, but also the social development and economic activity in the river basin. Based on the Brundtland Report, river sustainability is defined as "the development of water resources in the river basin to meet the needs of the present generation without compromising the ability of future generations to meet their own needs". Through an extensive review of literature and case studies on river basin management, we identify the five perspectives inherent in the concept of river sustainability, as listed below:

\section{Sufficiency}

The river system should have sufficient runoff of required quality to maintain the ecological health of the river while also supporting social settlements and economic activities within the river basin. It denotes the degree to which the river supplies the water needed for the production of the domestic demand for goods and services in the basin.

\section{Resilience}

Resilience is a measure of the ability of a system to absorb changes and still persist [18]. In ecological terms, the degree of resilience determines whether the system's functions remain unaffected, or decrease either temporarily or permanently [19]. The river system should have the capacity to respond to a perturbation (i.e. excessive discharge) or disturbance (i.e. water contamination) by resisting damage and recovering quickly. The vulnerability of communities to changing circumstances (e.g. climate, deforestation, infrastructure development) should not increase with time.

\section{Access}

Communities should have adequate access to the services provided by the river, such as water supply (including safe drinking water) and sanitation, recreation and transportation in order to meet essential requirements for ensuring the wellbeing of communities.

\section{Productivity}

The water resources should be used in a productive and efficient manner to provide socioeconomic development. The term 'water productivity' is similar to the terms 'labour productivity' or 'land productivity', but now production is divided by the 
water input. Water productivity could be measured either in physical output per unit of water, or monetary output per unit of water.

\section{Equity}

Equity inherent in sustainability has two aspects, intra-generational equity and inter-generational equity. Intra-generational equity refers to benefits and disbenefits, which arise from human use of the river system and should be fairly distributed among the various stakeholders. Intra-generational equity reveals the potential conflicts between current and future generations. Renewable water resources in the river system should not diminish with time. Water quality and ecological conditions of the river system should not degrade with time.

\subsection{PAM for measuring rivers sustainability}

This research applies Process Analysis Method (PAM) to develop and validate a framework for measuring sustainability of a large river basin. Deployment of PAM for river sustainability assessment involves five steps. The assessment starts with an in-depth review of the river system. The second step involves defining the term 'river sustainability', by addressing interests from stakeholders' perspectives. By interpreting sustainability in the context of river basin management, the assessment is structured to meet specific goals, thus meeting the needs of special interest groups. The next step is the core of the assessment: setting up the assessment by selecting and analysing a set of sustainability indicators. The indicators are chosen following the PAM to describe the effects of IIGs and EIGs on sustainability capital. Finally, the indicators and assessment framework is verified through reviewing and stakeholder consultation.

\section{Step 1. Overview of the river system}

The assessment starts with an in-depth review of the river functions and interconnections between river health and the social-economic state of the catchment, including flood discharge, sediment transport, ecosystem support, selfpurification, water abstraction, navigation, recreation, and hydropower generations.

\section{Step 2. Defining river sustainability}

PAM requires selection of an appropriate definition of the term sustainability. In our research, the working definition of a river basin is discussed in section 3.1. Five sustainability perspectives are identified to guide river sustainability assessment, namely, resilience to water-related risks, access to water supply and other services, productive use of water, and fairness between different users and generations.

\section{Step 3. Set up system boundary}

The system boundary is determined by two factors: the spatial and temporal scales [4]. Setting the system boundary is very important as it limits the processes to be included in the sustainability framework [20]. The spatial scale refers the physical size of the system. In the context of the present research, the river basin is 
composed of the following features: the entire geographical area drained by a river and its tributaries, and all its inhabitants and users of the associated river system. This temporal scale is set broad enough to cover both inner-generational and intragenerational effects.

\section{Step 4: Set up of sustainability assessment framework}

PAM considers the impact of the river system on the capital residing in the environmental, social and economic domains. By reviewing the system, activities that have impacts on river sustainability are identified. They are known as impact generators. Internal impact generators (IIGs) refer to activities within the river basin, whilst generators beyond the system boundary, such as global climate change, are the external impact generators (EIGs). Both IIGs and EIGs affect the store of sustainability value, in terms of environmental capital, social capital and economic capital. The consequences are described by sustainability indicators. Measurements for the indicators are consequently identified. Figure 4 illustrates the process by which impact generators affect the capital stores, of the three domains, and how the consequent issues are described by indicators. Finally, receptors of the impacts are named as external impact receivers (EIRs).

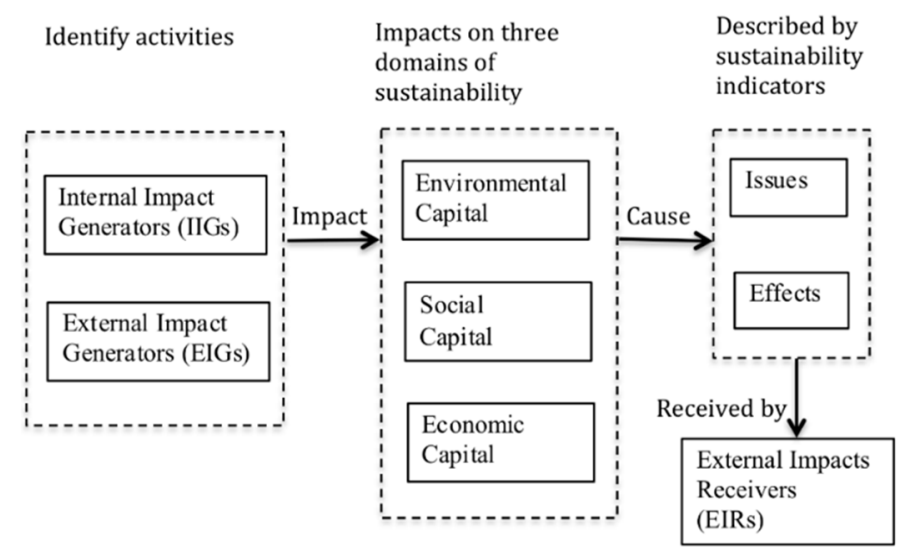

Figure 1: $\quad$ PAM sustainability assessment framework.

\section{Step 5: Verification}

The final step is to verify the analysis and conclusions obtained by applying the sustainability assessment framework. Having selected the indicators, relevant measurements for each indicator need to be carefully chosen and verified. Stakeholders are provided with the preliminary set of indicators as well as measurements to review. General questions for the stakeholders include whether the indicator set is holistic, whether any sustainability concerns have been omitted, whether additional indicators should be included, and whether any indicator appears to be poorly chosen. In cases where measurements are not available due to data scarcity and falsification, surrogate indicators need to be identified where possible. 


\section{Sustainability of the Yellow River: a case study}

\subsection{Background}

The Yellow River is the second-longest river in China after the Yangtze and the sixth-longest in the world. Rising in the Yueguzonglie Basin 4,500 $\mathrm{m}$ above sea level in the northern side of Bayankala Mountains, the Yellow River loops north, bends south, then flows eastwards for 5,464 km until it empties into the Bohai Sea (as shown in Figure 2). The Yellow River can be divided into three stages: the upper reaches, the middle reaches, and the lower Yellow River. Approximately $90 \%$ of the runoff enters the upper reaches of the Yellow River. The middle reaches of the river, passing through the Loess Plateau, extend from Hengkouzhen to Huayuankou. The Loess Plateau is a rapidly eroding basin consisting largely of thick deposits of aeolian loess. Sediment from the Loess Plateau accounts for $90 \%$ of the silt discharged to the river. The Lower Yellow River (LYR) traverses a course of $786 \mathrm{~km}$ from Huayuankou to the Bohai Sea, near Lijin in Shandong Province. Due to accumulation of sediment, the LYR is known as a 'suspended river', which has a riverbed with an average of $5 \mathrm{~m}$ higher than the surrounding ground beyond both banks. The Lower Yellow River also features a narrow basin, which accounts for only $4 \%$ of the total basin area, and a frequent changing river course due to silt-up of main channel.

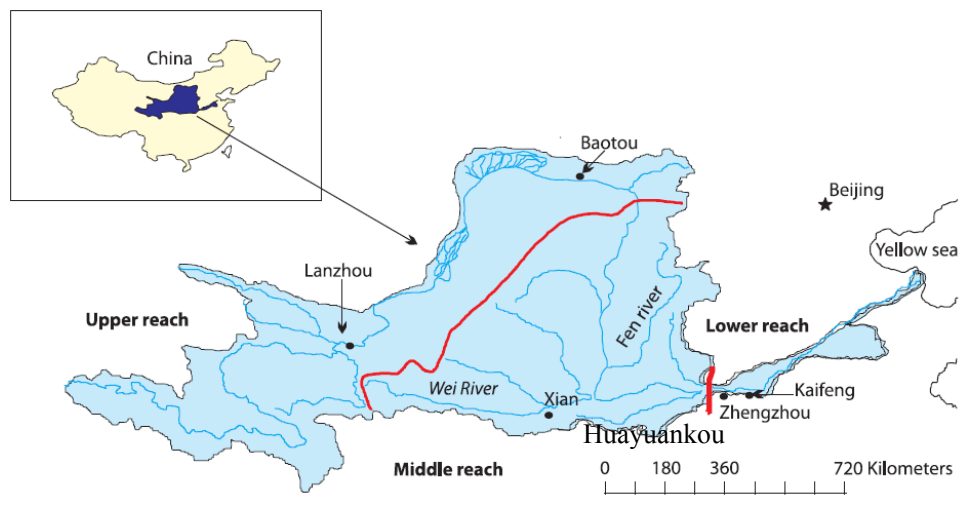

Figure 2: $\quad$ Map of the Yellow River Basin.

The Yellow River is famous for its excessive sediment. The average annual runoff of the Yellow River is 58 billion $\mathrm{m}^{3}$ and the average annual sediment transported in the Yellow River is approximately 1.6 billion tons [21]. This makes the average annual sediment concentration as high as $35 \mathrm{~kg} / \mathrm{m}^{3}$, which is unique compared to other river courses in the world [22]. The maximum sediment concentration as recorded at Xiaolangdi gauging station in 1997 is as high as $941 \mathrm{~kg} / \mathrm{m}^{3}$. Both the average sediment concentration and the total annual sediment load of the Yellow River are the highest in the world. 


\subsection{Sustainability assessment framework for the Yellow River}

Field trips to China were undertaken to engage the stakeholders for setting up the assessment framework, and to collect various data required for calculating river sustainability indicators. Visits were paid to Peking University (PKU), Yellow River Institute of Hydraulic Research (YRIHR), Yellow River Conservancy Commission (YRCC) during the trip. During the research trip, a road journey was undertaken along the Lower Yellow River (LYR). Starting from Huayuankou gauging station, located at the beginning of the standard dykes along the LYR, the journey covered a $150 \mathrm{~km}$ of the river reach. The visit enabled inspection of riverside facilities, dams, levees and the central channel. Standard dyke is the flood defence built along the riverbanks by YRCC, which is regulated by stringent standards. Being constructed since 2005, the standard dyke now function as flood defences, transportation hubs, and ecological restoration sites Social and economic activities in these villages, including agriculture, fishery and tourism, were observed. Following the road trip, stakeholder consultations were conducted at YRIHR and PKU. The consultations contributed greatly to understanding of the current status and emerging sustainability challenges of LYR, as well as the integrated river basin management strategies. The interviews also helped develop the working definitions of river sustainability and select a preliminary set of sustainability indicators.

\subsection{Sustainability indicators and indices}

Insights into the Yellow River's sustainability challenges have been gained through a comprehensive literature review and stakeholder interviews. By the application of the PAM, a sustainability assessment framework for the Lower Yellow River has been designed, leading to a tailored set of sustainability indicators, as shown in Table 1. The framework features three domains of sustainability, namely, environmental performance, social wellbeing and economic development.

Comprehensive data sets were collected during the field trip. During data processing, normalization methods, including standardization, rescaling, logarithmic transformation and category scales, are used to derive a notionally common scale of relative measurements. Normalization produces meaningful information by transforming indicators into dimensionless numbers on comparable scales. Each indicator is normalized to a score between 0 and 1, where 0 means unsustainable while 1 means sustainable. In order to gain a holistic view of river sustainability, a composite index is constructed for each domain, namely, the Environmental Performance Index $(E P I)$, Social Wellbeing Index $(S W I)$ and Economic Development Index $(E D I)$. The Composite indices condense and categorize the multi-dimensional information regarding the river's performance, further helping identify any trade-offs between the environmental capital, social and economic capital. Integrated scores for EPI are calculated as follows (SWI and $E D I$ are calculated in a similar manner),

$$
E P I_{i}=\sum_{j=1}^{n} E P_{j, i} / n
$$


Table 1: $\quad$ Sustainability indicators and sub-indicators for the Yellow River.

\begin{tabular}{|c|c|c|c|}
\hline \multicolumn{2}{|c|}{$\begin{array}{ll}\text { Notation } & \text { Indicators }\end{array}$} & $\begin{array}{l}\text { Sub-indicators/ } \\
\text { measurements }\end{array}$ & Metrics \\
\hline \multicolumn{4}{|c|}{ Environmental Performance Index $(E P I)$} \\
\hline \multirow{4}{*}{$E P_{1}$} & \multirow{4}{*}{$\begin{array}{l}\text { Environmental flow } \\
\text { indicator }\end{array}$} & High-flow volume (HFV) & $\mathrm{m}^{3}$ \\
\hline & & Highest monthly flow (HMF) & $\mathrm{m}^{3} / \mathrm{s}$ \\
\hline & & Low-flow volume (LFV) & $\mathrm{m}^{3}$ \\
\hline & & Lowest monthly flow (LMF) & $\mathrm{m}^{3} / \mathrm{s}$ \\
\hline$E P_{2}$ & Water quality indicator & $\begin{array}{l}\text { Ratio of monitored river section meets } \\
\text { Chinese national surface water quality } \\
\text { standard III }\end{array}$ & $\%$ \\
\hline$E P_{3}$ & $\begin{array}{l}\text { River channel capacity } \\
\text { indicator }\end{array}$ & LYR flood discharge capacity & $\mathrm{m}^{3} / \mathrm{s}$ \\
\hline$E P_{4}$ & $\begin{array}{l}\text { Sediment transport } \\
\text { indicator }\end{array}$ & Annual sediment load & $10^{9} \mathrm{~m}^{3} / \mathrm{yr}$ \\
\hline \multirow{3}{*}{$E P_{5}$} & \multirow{3}{*}{ Biodiversity indicator } & Zoo benthos (number of species) & Number \\
\hline & & Phytoplankton (number of species) & Number \\
\hline & & Fish (number of species) & Number \\
\hline \multirow[b]{2}{*}{$E P_{6}$} & \multirow[b]{2}{*}{ Land use indicator } & Changes in floodplain and wetland areas & $\%$ \\
\hline & & $\begin{array}{l}\text { Changes in soil erosion areas } \\
\text { (increased/restored) }\end{array}$ & $\%$ \\
\hline \multicolumn{4}{|c|}{ Social Wellbeing Index $(S W I)$} \\
\hline \multirow{2}{*}{$S W_{l}$} & \multirow{2}{*}{ Flood risk indicator } & $\begin{array}{l}\text { Frequency of flood events in terms of total } \\
\text { days of floods in the given year }\end{array}$ & Number/yr \\
\hline & & $\begin{array}{l}\text { Flood volume by Peak-over-threshold } \\
\text { method }\end{array}$ & $\mathrm{m}^{3}$ \\
\hline$S W_{2}$ & Drought risk indicator & $\begin{array}{l}\text { Number of functional no-flow days in a } \\
\text { year }\end{array}$ & Number/yr \\
\hline$S W_{3}$ & $\begin{array}{l}\text { Water consumption } \\
\text { indicator }\end{array}$ & Annual water abstraction & $10^{9} \mathrm{~m}^{3} / \mathrm{yr}$ \\
\hline$S W_{4}$ & Water access indicator & $\begin{array}{l}\text { Percentage of households with access to } \\
\text { drinking water }\end{array}$ & $\%$ \\
\hline$S W_{5}$ & $\begin{array}{l}\text { Wastewater discharge } \\
\text { indicator }\end{array}$ & $\begin{array}{l}\text { Percentage wastewater treated in gross } \\
\text { wastewater }\end{array}$ & $\%$ \\
\hline$S W_{6}$ & $\begin{array}{l}\text { Water allocation } \\
\text { indicator }\end{array}$ & $\begin{array}{l}\text { Implement of the } 1987 \text { Yellow River } \\
\text { Water Allocation Plan }\end{array}$ & $\%$ \\
\hline$S W_{7}$ & Public health & $\begin{array}{l}\text { Number of people exposed water } \\
\text { contamination incidents }\end{array}$ & Number/yr \\
\hline \multicolumn{4}{|c|}{ Economic Development Index $(E D I)$} \\
\hline$E D_{1}$ & Infrastructure indicator & Water storage capacity of major reservoirs & $10^{9} \mathrm{~m}^{3}$ \\
\hline$E D_{2}$ & $\begin{array}{l}\text { Hydropower } \\
\text { Indicator }\end{array}$ & Hydraulic power generation capacity & $\begin{array}{l}10^{9} \mathrm{kWh} / \\
\mathrm{yr}\end{array}$ \\
\hline$E D_{3}$ & Water utilities indicator & Water supply capacity & $10^{9} \mathrm{~m}^{3} / \mathrm{yr}$ \\
\hline$E D_{4}$ & $\begin{array}{l}\text { Wastewater treatment } \\
\text { indicator }\end{array}$ & Wastewater treatment capacity & $10^{9} \mathrm{~m}^{3} / \mathrm{yr}$ \\
\hline$E D_{5}$ & Institutional capacity & $\begin{array}{l}\text { Annual financial input in education and } \\
\text { institutional capacity building }\end{array}$ & $\begin{array}{l}10^{9} \mathrm{Yuan} / \\
\mathrm{yr}\end{array}$ \\
\hline
\end{tabular}


where $E P_{i}$ is the integrated environmental performance score of the given year $i$; $E P_{j, i}$ refers to the normalized score of the $j^{\text {th }}$ indicator in the environmental performance domain for the given year $i$; and $n$ is the number of available indicators in the environmental performance domain in that given year.

\subsection{Results and discussion}

The overall sustainability in terms of environmental performance, social welling and economic development of the Lower Yellow River is presented in Figure 3.

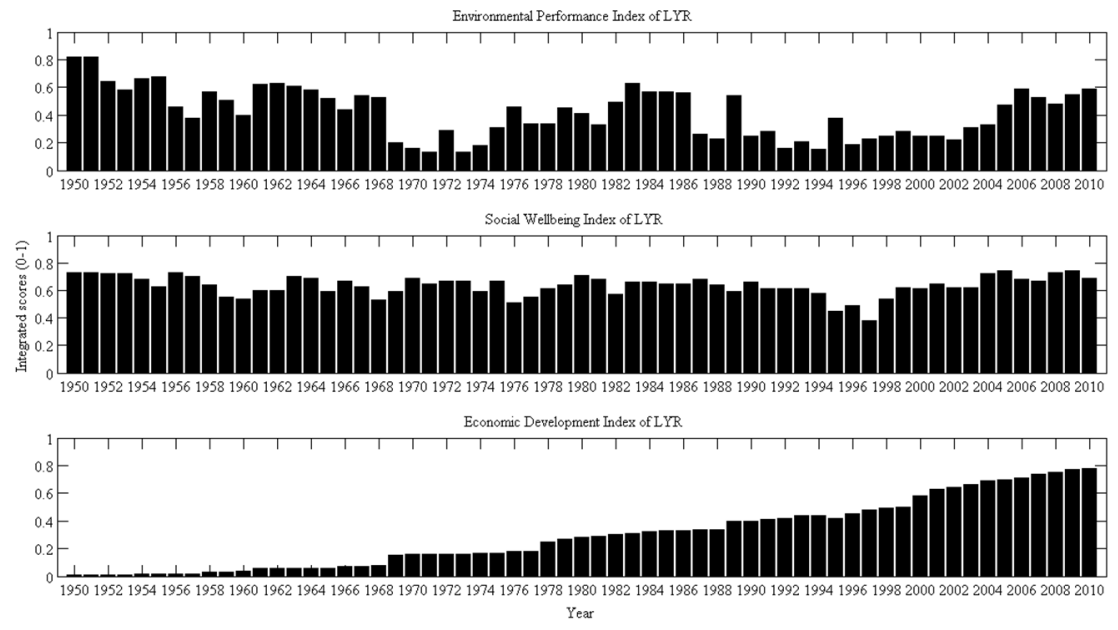

Figure 3: Sustainability of the Lower Yellow River from 1950 to 2010.

The results of EPI indicates that the environmental performance of LYR fluctuates over time. The worst situations are found in early 1970s and 1990s, mainly caused by excessive sediment and prolonged droughts respectively. EPI has gradually improved since 2003, owing to the establishment of Xiaolangdi Multifunctional Infrastructures. It has effectively evened the discharge over a hydrological year, maintained a continuous flow in the LYR and improved the channel capacity through flushing the silt.

The general social wellbeing in the LYR has been maintained at a stable, acceptable level; yet, a trade-off between water consumption and water access indicators can be identified. This reveals the inherent drawback of using an integrated index, which may hide important details and may result in loss of key information. For the economic development domain, a continuous, robust growth has been identified over the study period. This is because of extensive development of infrastructures for hydropower generation, flood defense, and water utilities associated with fast GDP growth. It is noted that the development infrastructure has brought many debates.

The results show that, although economic status for LYR have progressively improved since 1950, environmental quality declined in the latter half of the 20th 
century, with the lowest point occurring in 1997 when extreme drought occurred. YRCC implemented measures to improve the situation, mainly through multifunctional infrastructures and water allocation regulation. This effort proved to be effective, as the general sustainability subsequently improved.

\section{Conclusion}

Consistent with the Brundtland report, a definition of river sustainability was developed to incorporate the river system's interconnected physical, biological and socio-economic functions. We investigated quantitative measurements for river sustainability by using sustainability indicators. PAM has been employed as the guidelines for setting up the assessment framework and selecting indicators. It engages stakeholders at different stages of the assessment, who contribute to uncovering emerging issues and focusing attention on sustainability impacts.

A tailored indicator set was developed for the Yellow River. By performing the sustainability assessment, it reveals the trade-offs between the three domains of sustainability: environmental performance, social wellbeing, and economic development. The assessment provides policy-makers and river managers with a holistic review of the river basin. The framework tracks progress towards sustainable development and helps identify priorities during multi-criteria decision-making for integrated river basin management.

\section{References}

[1] WCED, Our common future, ed. G.H. Brundtland. 1987, Oxford: Oxford: Oxford University Press.

[2] Kates, R.W., et al., Environment and development: Sustainability science. Burlamacco Ristorante.

[3] Kates, R.W., T.M. Parris, and A.A. Leiserowitz, What is sustainable development? Goals, indicators, values, and practice. Environment, 2005. 47(3): pp. 8-21.

[4] Bell, S. and S. Morse, Sustainability indicators: measuring the immeasurable?, ed. S. Morse. 2008, London: London: Earthscan.

[5] Singh, R.K., et al., An overview of sustainability assessment methodologies. Ecological Indicators, 2009. 9(2): pp. 189-212.

[6] Pintér, L., et al., Indicators of Sustainable Development: Proposals for a Way Forward. 2005, IISD Publications. pp. 42.

[7] Ness, B., et al., Categorising tools for sustainability assessment. Ecological Economics, 2007. 60(3): pp. 498-508.

[8] Dalal-Clayton, D., Sustainable development strategies: a resource book, ed. D.B. Dalal-Clayton, et al. 2002, London: London: Earthscan.

[9] Falkenmark, M., The massive water scarcity now threatening Africa - why isn't it being addressed? Ambio, 1989. 18(2): pp. 112-118.

[10] Ohlsson, L., Water conflicts and social resource scarcity. Physics and Chemistry of the Earth, Part B: Hydrology, Oceans and Atmosphere, 2000. 25(3): pp. 213-220. 
[11] Brown, A. and M.D. Matlock, A Review of Water Scarcity Indices and Methodologies. 2011, The Sustainability Consortium, University of Arkansas.

[12] Boulton, A.J., An overview of river health assessment: Philosophies, practice, problems and prognosis. Freshwater Biology, 1999. 41(2): pp. 469-479.

[13] Karr, J.R., Defining and measuring river health. Freshwater Biology, 1999. 41(2): pp. 221-234.

[14] Norris, R.H. and M.C. Thoms, What is river health? Freshwater Biology, 1999. 41(2): pp. 197-209.

[15] Norris, R.H. and C.P. Hawkins, Monitoring river health. Hydrobiologia, 2000. 435: pp. 5-17.

[16] Rapport, D.J., R. Costanza, and A.J. McMichael, Assessing ecosystem health. Trends in Ecology \& Evolution, 1998. 13(10): pp. 397-402.

[17] Li, G., Maintaining the Healthy Life of the Yellow River. 2005, Zhengzhou: Yellow River Conservancy Press.

[18] Becker, J., Measuring progress towards sustainable development: An ecological framework for selecting indicators. Local Environment, 2005. 10(1): pp. 87-101.

[19] Conway, G.R. and E.B. Barbier, After the green revolution: sustainable agriculture for development. After the green revolution: sustainable agriculture for development, 1990.

[20] Chee Tahir, A. and R.C. Darton, The Process Analysis Method of selecting indicators to quantify the sustainability performance of a business operation. Journal of Cleaner Production, 2010. 18(16-17): pp. 1598-1607.

[21] Li, G., Questions and Answers about the Yellow River. 2009, Zhengzhou: Yellow River Conservancy Press.

[22] Chen, J., Harness and Development of the Water Resources in the Yellow River-Integrated Volume, ed. J. Chen. Vol. 1-3. 1998, Zhengzhou: Yellow River Hydraulic Engineering Press. 